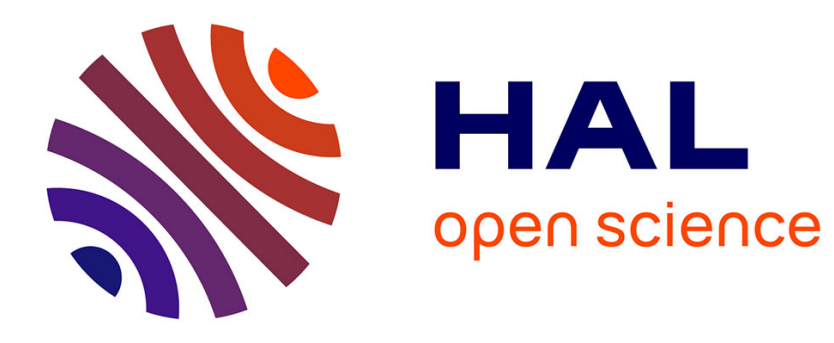

\title{
'Strict' anadeixis, discourse deixis and text structuring
} Francis Cornish

\section{To cite this version:}

Francis Cornish. 'Strict' anadeixis, discourse deixis and text structuring. Language Sciences, 2011, 33

(5), pp.753-767. hal-00966803

\section{HAL Id: hal-00966803 \\ https://hal-univ-tlse2.archives-ouvertes.fr/hal-00966803}

Submitted on 27 Mar 2014

HAL is a multi-disciplinary open access archive for the deposit and dissemination of scientific research documents, whether they are published or not. The documents may come from teaching and research institutions in France or abroad, or from public or private research centers.
L'archive ouverte pluridisciplinaire HAL, est destinée au dépôt et à la diffusion de documents scientifiques de niveau recherche, publiés ou non, émanant des établissements d'enseignement et de recherche français ou étrangers, des laboratoires publics ou privés. 
'STRICT' ANADEIXIS, DISCOURSE DEIXIS AND TEXT STRUCTURING

(Article published in Language Sciences 33(5): 753-767, 2011)

\section{Francis Cornish}

Université de Toulouse II-Le Mirail

and CNRS CLLE-ERSS, UMR 5236,

5, Allée Antonio-Machado,

31058 Toulouse Cedex 09

France

Email: cornish@univ-tlse2.fr 


\begin{abstract}
Taking English as the example language, the article begins by presenting a Scale of indexicality characterizing context-bound expression types, ranging from those signalling pure deixis at one pole, to ones expressing pure anaphora at the other. On the basis of this Scale, the article attempts to determine the specific way in which demonstratives (pronouns as well as NPs) may realize the discourse procedures of deixis and "anadeixis" - a referring procedure that involves partly anaphoric, and partly deictic reference.

It is the discourse-structuring function of deictic and anadeictic indexicals that is the particular focus of the article. Textual examples are presented and analysed of anadeicticallyfunctioning demonstrative NPs (whether of the 'strict' anadeixis or the discourse-deixis type) that are either initial or non-initial within their discourse unit, and which serve either to herald a transition between major discourse units within a given text, or to actually implement one. Demonstrative expressions may also serve to switch the focus back to an earlier topical referent or discourse unit, which will have since been superseded by a more recent topic or unit. The current unit then further develops that earlier topic or discourse unit.

It is the deictic property of demonstratives, coded morphologically in English via their proximal vs. distal character, along with the nature of the predicative component of the expression where it is a lexical NP, which enables such expression types to perform the discourse-structuring roles at issue here. As such, this component may not correspond to presupposed information, but rather performs a (re-)classifying or predicating function.
\end{abstract}

Keywords: Anadeixis; Anaphora; Deixis; Discourse; Discourse deixis; Indexicality 


\section{Introduction}

Much work on demonstratives (determiners and pronouns) has dealt with their intrinsic semantic and indexical properties, highlighted in particular by contrast with those of definite articles and $3^{\text {rd }}$ person personal pronouns: cf. Kleiber (1983), (1984), (1986a,b), (1990), (1994), (2006); Corblin (1983a), (1987), (1995); Guillot (2007), De Mulder (1997), (1998), (2007) for French, and Diessel (1999), (2006); Himmelmann (1996); Lyons (1975), (1977); Levinson (2004) and Maes and Noordman (1995) for English, among other languages (for the systems of demonstratives and their potential uses in a range of languages, see the very detailed study in Gerner, 2009). Not many works, however, have examined the particular distribution of demonstrative-based expression types within whole texts (whether spoken or written), as a function of the structure of the discourse that may be associated with such texts (but cf. Maes, 1996, Guillot, 2007 and my own work, Cornish, 2008, 2009a). Although a number of studies do indeed examine the use and interpretation of indexical expressions of various types within texts (mainly literary ones: see for example Corblin 1983b, Gary-Prieur and Noailly, 1996 and Kleiber, 1998), they tend to deal with the effect of context on the interpretation and function of such expressions, rather than with their discourse-structuring contribution. Demonstratives have very specific contributions to make to the structuring of the discourse associated with texts, and this is as a function of the particular bundle of semanticpragmatic properties associated both with the demonstrative itself, and with the head noun of an NP of which it is the determiner, where this is the case. De Mulder (1997, pp. 187-192), at the end of a long chapter devoted to demonstratives in French, began to examine the textual functioning of demonstratives - though without illustrating this in terms of long(ish) texts (that is, consisting of more than one paragraph in the written medium).

Two principles lie behind the discussion in this paper: first, that it is not very revealing to examine either deixis or anaphora in isolation from the entire spectrum of indexical procedures available in natural languages: after all, deixis and anaphora as well as the linguistic devices which serve to realise them in context are integral parts of a whole network of indexical procedures (see Fig. 2 at the end of section 3 below) and so need to be envisaged one in terms of the other. And second, that indexical expressions - context-bound 'pointing' devices - only manifest their true values in the context of entire texts, whether spoken or written: indeed, they are intimately bound up with the structuring of the discourse that may be associated with a given text in some context, as we shall see in what follows (in section 4 in particular).

My aims in this article then are, first, to argue for a scalar conception of the relationship between deixis and anaphora, bridged via the intermediate notion of 'anadeixis': see Ehlich (1982) for the introduction of this term; however, in this chapter, Ehlich merely established the notion, and did not set up the sub-categories to be developed in what follows (section 2). I will then characterise anadeixis in terms of three distinguishable subtypes: 'strict' anadeixis, ${ }^{1}$ recognitional anadeixis, and discourse deixis (section 3). For the remainder of the article, I shall exploit this three-way distinction in pinpointing various key discoursestructuring functions within particular texts which such context-bound referring procedures may realise (section 4). The example texts will all be taken from English.

\section{Deixis and anaphora: a scalar conception}

\footnotetext{
${ }^{1}$ Realised by what Diessel (1999) calls 'anaphoric demonstratives': reference back to referents already present in a given discourse representation, but which are not fully topical, or (in more general terms) are not the ones whose anaphoric maintenance would be expected at the point of occurrence. Diessel does not use the term 'anadeixis' in this respect, however.
} 
Deixis and anaphora are conceived here as complementary discourse-referring procedures which the user exploits in constructing, modifying and accessing the contents of mental models of an unfolding discourse represented in the minds of speaker and addressee (or writer and reader in the written form of language): see Cornish (2009a), (2010). Basically, they are procedures for coordinating the speech participants' attention throughout the flow of text as produced within a given context to which they are both party (see in particular Clark \& Bangerter, 2004 on this issue, in terms of the act of referring more generally). These procedures operate as a function of 'addressee-centredness' (Jones, 1995, p. 47) or of the principle of 'Recipient Design' (see Bell, 1991 in relation to media discourse).

Deixis serves prototypically to direct the addressee's attention focus towards a new discourse entity - or to a new aspect of an already-existing discourse referent — which is derived by default via the context of utterance, whose centre point is the hic et nunc of the speaker's verbal and non-verbal goal-directed activity (see also Diessel, 2006, p. 470), but may be transposed (Levinson, 2004, pp. 103, 107; Lyons, 1982, p. 119: see Bühler's, 1990 notion Deixis am Phantasma). ${ }^{2}$ This is the reason why I used the term "default" in the last but one clause above. Deixis in this discourse-cognitive perspective involves the exploitation of the utterance context (the deictic ground, in Hanks', 1992, 2009 terminology) in order to profile a figure: a new referent or a new conception of an existing referent within the discourse memory. Deixis is one (very essential) way of 'grounding' the discourse to be created by the production of text in some appropriate context: it is context-establishing in that it sets particular values of the basic contextual parameters (deictic space - deictic time current speaker's and addressee's roles - source of viewpoint) for the communicative event, setting up the subjective viewpoint or perspective within which that discourse is to be construed and hence constructed (cf. also Oakley, 2009, pp. 173-4). We have to do with deixis every time we need to have recourse (by default) to some key feature of the context of utterance (i.e. an 'index': see Nunberg, 1993; de Mulder, 1997; Recanati, 2005) in relation to the very production of the utterance itself, in order to identify the referent intended by the speaker. A canonical example is given in (1):

(1) Hey, look at that! [The speaker gestures towards a strange-looking bird perched on a branch of a nearby tree]

Here, the existence of the intended referent ('the strange-looking bird on the tree close to the interlocutors'), which is available within the utterance context, is being drawn to the addressee's attention as a function of the very act of utterance involved. It is not presupposed already to exist and to be salient within the latter's attention focus, as is the case with canonical anaphoric references. Rather, its existence is asserted (or, more accurately, demonstrated). The distal demonstrative that (and not proximal this) is used here, since the speaker's intention is evidently to secure a joint orientation of the interlocutors' attention focus on the intended referent. The deictic procedure adopted results in the intended referent "standing out" from within its context, thereby acquiring a high level of psychological salience for both speaker and addressee; so it is introduced into the discourse as a new unit of

\footnotetext{
${ }^{2}$ A good attested example of this is given in Rubba (1996, p.227): [Excerpt from an interview with an inhabitant of San Diego:] "There's a part of southeast San Diego where you go down, you see all these Vietnamese theaters and everything in Vietnamese and when I see that I just kind of feel, well, I don't belong in this place, this is where the Vietnamese people are, I don't belong here." It is clear here that the move from the use of $2^{\text {nd }}$ person pronouns in the first two clauses to the $1^{\text {st }}$ in the remainder of this extract, together with the use of the perception verbs see and feel in the third and fourth, shows that we are in a "shifted mental space" in which the speaker presents herself as travelling vicariously through the neighbourhood being evoked; hence the proximal demonstratives this (both as determiner and pronoun) and here are used as a function of this transposed deictic configuration.
} 
information. Once it has been installed in the addressee's working memory, it may felicitously be retrieved via one or more anaphoric reference(s).

By contrast, anaphora consists in the retrieval via a referentially-dependent indexical expression token from within a given ground of an already existing 'figure' (or one which may be relatively easily accommodated or otherwise inferred from context), together with its 'ground', the anaphoric predication acting to extend that ground (see Kleiber 1994, Ch. 3) i.e. to carry it over for the interpretation of the current utterance. So in fact the 'figure/ground' relation is an integral part of the operation of these two indexical referring procedures. The occurrence of an anaphor together with the clause in which it occurs as a whole constitutes a signal to continue the focus of attention established - or assumed to be established - at the point of use. It is an instruction as if to say: 'Keep things as they are - no change. Business as usual'. For a canonical example of anaphora, see the occurrence of it in the possible continuation of the utterance in (1):

a. ...I wonder how it got there.

The occurrence of it in (1a) presupposes that its intended referent is already known to the addressee and is indeed uppermost in his/her mind at the time of utterance. That is, it is already highly salient psychologically, and so requires only minimal coding.

Now, canonical (i.e. situational) deixis and discourse anaphora are but special instances on a cline of indexical reference, and are by no means mutually exclusive or 'absolute' referring procedure types. Given that anaphora is derivative upon deixis, as Lyons $(1975 ; 1979)$ convincingly argued, we may expect there to be a degree of overlap in between what we might term 'pure deixis', on the one hand, and 'pure anaphora', on the other. And this is indeed the case, as we will see shortly. I have tried to capture this relationship in the Scale of indexicality represented in Figure $1 .^{3}$ See note 4 for the key to the abbreviations of the categories of expression retained here.

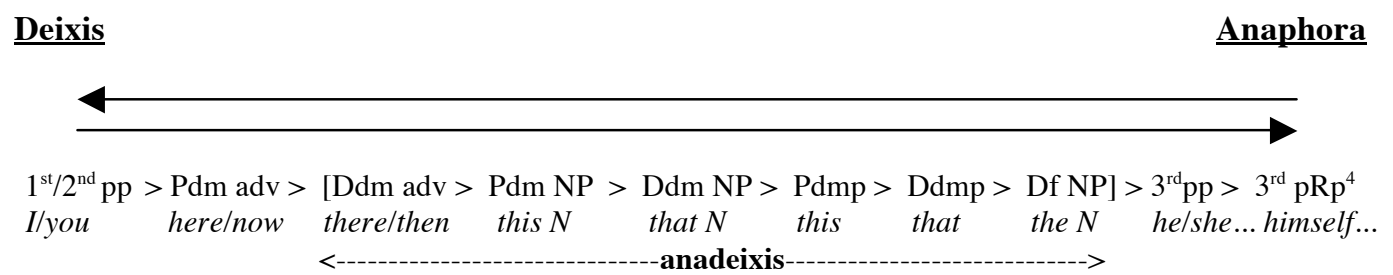

Figure 1: Scale of indexicality coded by certain categories of indexical expressions (Cornish 2007, Fig. 1, p. 149 - slightly revised)

\footnotetext{
${ }^{3}$ I follow Levinson (2004, p. 97) and Nunberg (1993) in using the term 'indexicality' to denote the use of context-bound or context-pointing expressions generally (whether that use is strictly deictic, anaphoric, or context-bound in some other way), and 'deixis' to refer to the use of expressions with in-built indexical functioning.

${ }^{4}$ Key to the abbreviations used in Figure $2:$ ' $1 \mathrm{st}^{\mathrm{st}} / 2^{\text {nd }} / 3^{\text {rd }} \mathrm{pp}$ ': “first/second/third person pronoun"; ' $\mathrm{P}$ ': “proximal”; ' $\mathrm{D}$ ': "distal”; ‘dm': “demonstrative”; 'adv': “adverb”; 'NP': “noun phrase”; ‘p': “pronoun”; 'Df’: “definite”; 'R': "reflexive”.
} 
Figure 1 is an attempt to range various categories of indexical expressions on a Scale of phoricity in terms of their relative degrees of inherent indexicality. See also Consten (2003) for a similar view, ${ }^{5}$ as well as Diessel's (1999, p. 113) comparable - though much reduced in relation to Fig. 1 above - scale presented as Figure 6, which he conceives in terms of a cline of grammaticalization. I have represented the indexical expression types retained in terms of their category type, and not in terms of the actual forms involved. However, I have placed one or more representative indexical expressions below each category on the Scale, for purposes of illustration.

The continuous nature of the relation between strict deixis and strict anaphora, passing through 'anadeixis' as an intermediate phase (partaking of both these context-bound referring procedures), reflects the priority of deixis over anaphora, which presupposes it both ontogenetically $^{6}$ and phylogenetically. ${ }^{7}$

The parallel unbroken lines ending in arrows pointing towards each pole are intended to indicate that deixis and anaphora are not mutually exclusive, 'absolute' indexical categories, but that the majority of the various indexical expression types which may realise them share both properties, albeit to differing degrees (for Gerner, 2009, pp. 69-70, as for Bühler, 1990, anaphora is a sub-type of deixis, in fact). After all, several types of indexical expression may have either a deictic or an anaphoric function in a given context - e.g. distal demonstrative adverbs (for instance, then, there), $3^{\text {rd }}$ person demonstrative pronouns and determiners, and even definite NPs (see also Levinson, 2004, p. 111 and examples (2) and (3) below); and in their anaphoric use, demonstrative-based expressions may have a partlydeictic, partly-anaphoric (i.e. 'anadeictic', see Ehlich, 1982, pp. 333-4) function in referring contextually. See also Diessel (1999, pp. 96-100) and Lyons (1977, p. 676). We will be focusing more particularly on "anadeixis" and its various subtypes in section 3 below.

As already pointed out, the rationale for the hierarchy lies in the degree of inherent 'indexicality' of each individual indexical category retained. The two poles are occupied, respectively, by $1^{\text {st }}$ and $2^{\text {nd }}$ person personal pronouns, which are primary deictics functioning token-reflexively and may not be used anaphorically (contrary to what is stated in Martin, 1992, pp. $127-8$ for English $I / m e / m y$, at least) and by $3^{\text {rd }}$ person reflexive pronouns, which (at least when unstressed in English) function only anaphorically as bound variables within a highly constrained clause-bound context.

As for the central 'anadeictic' span on the Scale, the demonstrative adverbs (e.g. now/then, here/there) are placed at a higher position on the Scale (i.e. further to the left) than the NPs, since they are potentially 'token-reflexive' items, like the $1^{\text {st }}$ and $2^{\text {nd }}$ person pronouns; however, unlike these, the distal members of each pair, at least, can be used anaphorically —or rather "anadeictically"-: e.g. then, there. See Himmelmann (1996, pp. $245-6$, n. 12) for cross-linguistic evidence that demonstrative determiners and pronouns are often historically derived from demonstrative adverbs, which are more basic expression types. See Kleiber $(2008$, p. 143) on the inability of the French equivalent of the proximal spatial demonstrative adverb here, ici, to function anaphorically, and De Mulder \& Vetters (2008, p.

\footnotetext{
5 However, I do not share Consten's claim in this chapter that there is no essential or useful distinction to be made between 'deixis' and 'anaphora'. See also below on this issue.

6 In other words, in terms of the progressive mastery of his native language by the child. The latter starts out by using demonstrative expressions to refer in context, and it is only much later that he develops other indexical expression types. Anaphora is usually a later, more complex type of referring procedure in child language development. See Karmiloff-Smith (1980), Tanz (1980) and Clark (1978) in this connection.

${ }^{7}$ I.e. having to do with the development over time of new types of indexicals in the world's languages. Demonstrative-based expressions seem in this respect to be thoroughly basic (non derived), having existed as far back as records go in both present-day and earlier languages. It is from these expression types that the other, relatively more recent indexical expression types have been derived (e.g. in those languages which have them, definite articles and $3^{\text {rd }}$ person pronouns).
} 
15) on the same property claimed to be associated with the use of the French proximal temporal deictic adverb maintenant ('now'). Both these works argue that the proximal members of these indexical adverb pairs are nonetheless "token-reflexive", like the English primary deictic pronouns I/me, you; but unlike the latter, they are "opaque" (Kleiber, 2008) or "impure" (De Mulder \& Vetters, 2008) indexical expression types. That is, their referent is not automatically yielded by virtue of their very occurrence in an utterance token, but, as in the case of the demonstrative NPs and pronouns, needs to be inferred by the addressee on the basis of context.

The lexical NPs on the Scale are placed to the left of the corresponding pronouns. All demonstrative-based categories are placed above the definite NP category: I have placed definite NPs at the lower limit of the 'anadeictic' span in Figure 1, since though they are not always indexical in function, ${ }^{8}$ they may yet occur deictically as well as anaphorically. An (attested) example of their possible deictic use is given below:

(2) “(...) I felt the quake first at about 0915. I went out on my balcony in the hotel where I was - it was a beautifully calm day - and talked to others on their balconies. The quake felt very slight so we thought little of it.

About 45 minutes later, I noticed that water had receded from Patong Bay. We'd never seen it before and we could hear people on the beach talking about it. (...)" (Troy Husum, "Eyewitness: Panic in Patong", BBC News on the web, 27.12.04)

This extract is taken from the very beginning of an oral eyewitness account of the destructive tidal wave which hit the shores of the Indian ocean in December 2004. As the extract makes clear, the narrator was on his hotel balcony in Patong, Thailand very near the beach in question when he first noticed the developing wave and its eventual breaking on the shore. The referent of the definite NP the beach here is evidently 'the beach in Patong Bay which was in the speaker's immediate vicinity at the time of utterance'.

Another attested example is given in (3), an oral exchange that occurred between Roy Hattersley, then UK Home Secretary, and the British ambassador to Romania at the time (1976). RH had just begun an official visit to Romania, and had stepped out of his plane in order to inspect the guard of honour awaiting him on the runway, when the ambassador rushed up out of breath:

(3) British ambassador: "The prime minister has just resigned!"

Roy Hattersley: "What, their prime minister?"

Ambassador: "No, not THEIR prime minister, OUR prime minister!" (example

(2.22) in conjunction with note 27 in Cornish, 1999: 58)

RH's initial interpretation of the British ambassador's definite NP the prime minister was evidently a deictic one (on the basis of the utterance context, where the place of the exchange was Romania); this yielded as referent 'the PM of Romania'. ${ }^{9}$ But the incoherence of this interpretation quickly became apparent, given the status of both interlocutors (the fact that

\footnotetext{
8 They may refer independently in terms of their lexical content when this is sufficient to uniquely identify their referent. See the NPs the proprietor of La Voile Rouge beach restaurant in text (10) (line 1), and the billowing smoke of a car wreck in text (13) (lines 10-11) further on (section 4): note that these are introductory, not subsequent (anaphoric or anadeictic) references. So the definite article should not, in my view, be characterized as 'inherently' deictic, as is the case in Martin (1992, p. 116): cf. his term 'deictic the'. See also the term 'deictics' construed as a linguistic category (in place of the more traditional term 'demonstratives') adopted by Lapaire \& Rotgé (1992).

${ }^{9}$ This type of reference is close to what Fillmore (1997) calls "symbolic deixis", as in examples like This weather! or This country!.
} 
they both officially represented the UK): why, in such circumstances, would the ambassador be so concerned to inform RH, then British Home Secretary, that the PM of Romania had resigned?

The ambassador's correction in his second turn of this brief exchange oriented his addressee towards the usual referential procedure associated with the use of definite NPs, which is to invoke a shared set of potential referents on the basis of the wider context in which the expression token was used - here this would be the country which both interlocutors officially represented at the time of utterance - and to favour an interpretation of the intended referent as being located inclusively within this domain (cf. Hawkins, 1978; Lyons, 1999). In (3), this would yield as referent 'the Prime Minister of Britain at the time of utterance - Harold Wilson'. In this way, the pragmatic relevance of the initial utterance as a whole would be maximised.

Unlike demonstrative NPs, the denotation of the head noun in singular definite NPs constitutes presupposed information at the moment of utterance. The expression as a whole presupposes the uniqueness of the intended referent within the activated shared set of referents, and refers inclusively to all the members of the set, under Hawkins' (1978) account. This makes definite NPs more suited than demonstrative NPs to realising anaphora rather than deixis (though this latter value is still possible with the use of definite NPs, as both (2) and (3) illustrate). Demonstrative-based expressions, on the other hand, carry no presupposition of the uniqueness of their referent (quite the reverse, in fact), and refer exclusively to one member (or one subset of members) within a given shared set of entities. In particular, where they are determiners, the head noun in conjunction with any expansion has a classifying or implicitly predicating function in relation to the referent singled out by the NP as a whole.

Clearly, then, the inherent degree of indexicality associated with definite NPs is lower than that of the demonstrative-based categories retained (unlike these, for example, they cannot be used to realise 'discourse deixis', as we will be seeing in section 3 later on), but higher than that of (unstressed) $3^{\text {rd }}$ person pronouns, which are normally restricted to the anaphoric function. Though their default use is to express anaphora, they may be used deictically, 'anadeictically' (see below) as well as non-indexically, as we have partly seen. See also Corblin (1983a), (1987), Kleiber (1986a; 1986b) and De Mulder (2007, pp. 176-182) on the differential 'deicticity' of the French equivalents of English demonstrative vs. definite full NPs (ce $N$ vs. le $N$, respectively). Note also that placing definite NPs closer to the 'anaphoric' pole of the Scale than demonstrative expression types is contrary to both Ariel's and Gundel, Hedberg \& Zacharski's hierarchies (regarding Ariel's characterisation, see the criticism in De Mulder, 1997, pp. 147-8). Phylogenetically, this reflects the diachronic development of the definite article, in those languages which possess it, from an earlier demonstrative form, rather than vice versa.

This conception appears to run counter to the view of definite NPs presented in Epstein (2002), however. This is that such expression types code the low cognitive accessibility of their intended referent; nevertheless, Epstein claims throughout the article (e.g. on pp. 349, 355) that they serve to convey the "discourse prominence" of that referent. While they may well have uniquely identifiable and/or familiar referents, they do not code such statuses lexically (p. 334). At the same time, he claims that certain uses of the definite article reflect the "high topicality" of the intended referent (pp. 339, 349). It is difficult to see how "low accessibility", on the one hand, may be squared with "high topicality" and "discourse prominence", on the other. In fact, the interesting attested examples Epstein presents invariably have the (reduced) definite NP (e.g. the mosquitoes, ex. (7), p. 350, and the fire, ex. (10), p. 354) occurring before the information required to establish the referent at issue is made available. In each case, however, it is clear that the assumption of prior familiarity with the referent on the addressee's or reader's part has been violated, and that it is 
precisely this violation which renders such references discourse-prominent. So far from counter-exemplifying standard accounts of definite NP references in terms of familiarity or unique identifiability, Epstein's examples actually support them.

The demonstrative-based expression types ranged in between the two polar categories on the Scale are ordered in terms of the proximal (marked) vs. distal (unmarked) distinction which they carry morphologically in English - the marked counterpart bearing a higher degree of indexicality than its unmarked one (cf. Lyons, 1975 and the point made by Levinson, 2004, p. 121, n. 4, in relation to the privative opposition between this and that).

High pitch and heavy stress placed on a token of a given expression type (e.g. a $3^{\text {rd }}$ person pronoun) move it one position higher towards the 'Deixis' pole on the scale. ${ }^{10}$

\section{Anadeixis: 'Strict' anadeixis, recognitional anadeixis, and discourse deixis}

'Anadeixis' is the type of indexical reference which combines the anaphoric and deictic procedures to different degrees. That is, the indexical expressions which realise it are anaphoric to the extent that their referent is already (potentially) present in the discourse representation assumed by the speaker to be shared by speaker and addressee at the point of occurrence, and is retrieved via this reference; however, that referent is less than highly salient at the point of use, unlike the situation which prevails with canonical anaphora. And it is deictic to the extent that the speaker is having recourse to the utterance context to redirect the addressee's attention focus to a referent which, although potentially available within the discourse context at the time of utterance, is not the one to which subsequent reference would be expected to be made at that point. It is not canonically deictic, in that no totally new referent is being introduced into the discourse thereby, and not all the utterance-level parameters are being altered via this reference.

Three main sub-types of anadeixis may be distinguished: 'strict' anadeixis, recognitional anadeixis, and discourse (as well as textual) deixis. Let us examine these briefly in turn.

\section{1 'Strict' anadeixis}

The prototypical instance of anadeixis (what I am calling 'strict anadeixis') lies in the anaphoric use of demonstratives (pronouns and NPs), whereby they direct the addressee's attention to some referent already evoked in the surrounding discourse, but which is less than fully topical at the point where the retrieval is made; or where there is competition between more than one referent of a given type; or where a macro-topical discourse referent has just been introduced and needs to be firmly installed in the addressee's short-term memory span.

Diessel (1999) in fact calls the expression types realising this type of use 'anaphoric demonstratives' (see also Kleiber, 1990 for discussion of the French equivalents). In German, this type of indexical reference would require the use of one of the pronominal counterparts (bearing identical forms) of the definite articles der 'the M.SG', die 'the F.SG' or das 'the N.SG', rather than the (purely anaphoric) $3^{\text {rd }}$ person pronouns er 'he', sie 'she' or es 'it', respectively (see Bosch et al., 2007 on the indexical and grammatical properties of these two types of pronoun; and Bosch and Umbach, 2007 more specifically for their indexical properties). And in French, one of the disjunctive $3^{\text {rd }}$ person pronouns lui 'he'/'it', elle 'she'/'it', eux 'they M.PL' or elles 'they F.PL' (all accented), rather than one of the clitic (unaccented) pronouns le, la, les, lui or leur. See also Gerner (2009, pp. 70-71) for a

\footnotetext{
10 High pitch and heavy stress may be viewed as kinds of vocal gestures. As such they constitute the indexical, deictic part of such expression types.
} 
presentation of certain dedicated "anaphoric demonstratives" bearing this type of reference in Iaai (ex. (52)) and Malagasy (exs. (53) and (54)). In none of the types of situation mentioned above would an unstressed $3^{\text {rd }}$ person pronoun be capable of ensuring the maintenance of the intended referent -its vocation being canonically anaphoric. See as an initial illustration of 'strict' anadeixis the use of the proximal demonstrative pronoun these in (4):

(4) “Asia

\section{Pakistan quake toll tops 73,000}

The death toll from Pakistan's earthquake soared to more than 73,000 and could still rise, according to official government figures. These are lower than those of other agencies, which estimate up to 87,000 dead. More than 3 million have been left homeless across Kashmir and North Western Frontier province." (The Guardian Weekly 11-17 November, 2005, p. 2).

In (4), the proximal demonstrative pronoun these, subject of the second sentence, refers "anadeictically" to 'the official Pakistani government figures $\left(73,000\right.$ as of $11^{\text {th }}$ November 2005) on the death toll from Pakistan's then recent earthquake'. This referent has just been evoked via a grammatically and discursively peripheral expression, the adjunct PP according to official (Pakistani) government figures in the initial sentence of the text. This is a sentence modifier/adjunct specifying the source of the claim made by the journalist in the main part of this initial sentence; as such, it occupies a backgrounded slot, in discourse terms. Indeed, this referent could not have been retrieved felicitously via a canonically anaphoric expression (here \#they), since it is not in focus at the point of occurrence. In addition, the use of a demonstrative expression here is motivated by the contrast being conveyed between the official Pakistani figures on the death toll and those of certain "other" agencies, which are different. Contrast is an in-built feature of demonstratives in general. Both these factors are motivating the "anadeictic" use of a demonstrative pronoun here. See also McCarthy (1994, pp. 272-3) on the attention-focus shifting function which this/these may realise in discourse.

\subsection{Recognitional anadeixis}

An initial attested example of "recognitional" anadeixis is given in (5):

(5) Tony Blair was said to be on the phone last week to his German oppo, Chancellor Schröder, trying to talk through an upbeat final instalment of that dismal industrial soap opera called Longbridge... (The Guardian, 2000: ex. (5) in Cornish, 2001, p. 300)

In (5), the reference via the distal demonstrative NP that dismal industrial soap opera called Longbridge is a "complicitous", tongue-in-cheek allusion to the sale of Rover by the German firm BMW (as if to mean "you know the one I'm talking about!"), which had been front-page news over the previous weeks in The Guardian, as well as in the UK press and media generally; so the journalist could justifiably assume that a representation of this situation would be prominently stored in the reader's episodic memory.

(6) [Sticker on rear window of car] Mind that child! He may be deaf. (Ex. (6) in Cornish, 2001, p. 300)

In (6), the distal demonstrative NP that child also conveys a "reminder" to the addressee (the driver of the car assumed to be just behind the one on which the sticker is displayed), but this 
time the predicational and positional context invokes a stereotypical frame assumed to be buried deep in drivers' long-term (semantic) memories: such a frame consists of a representation of a situation (feared by all motorists) whereby a reckless child, without checking beforehand, suddenly rushes out into the street and into the trajectory of a vehicle and is killed or maimed as a result. The use of the distal demonstrative NP, in conjunction with the utterance situation assumed by the text as a whole, serves to activate and extract this stereotypical representation from semantic memory and to focus attention on its central protagonist, the sub-category of pedestrian corresponding to a "reckless, and potentially deaf, child" (the reference is clearly to a stereotype). As in example (5), the use of determiner that, here introducing a superordinate noun (child), is equivalent to the exclamation "you know the type I mean". As also in (5), the distal demonstrative determiner has evidently been chosen in order to instruct the reader to seek the intended referent at some remove from the circumstances of utterance, and to signal a shared writer-reader orientation.

In both (5) and (6), there is a deictic aspect to the reference of the demonstrative NP, in that the speaker is clearly orienting the addressee's attention toward a particular shared representation in long-term, episodic or semantic memory (this is the raison-d'etre of the predicate modifiers within the NP itself in (5) and of the continuative second utterance in (6), which act as memory retrieval cues); but at the same time, there is an anaphoric dimension, since the use of the NP is presupposing the prior existence of the shared representation within the addressee's memory. It is in no sense an attempt to construct such a memory representation, a situation which a canonical deictic reference would realise. But this reference is nonetheless more clearly deictic than anaphoric, since the addressee's attention cannot be assumed already to be focused upon the intended referent in these examples - even peripherally, as is the case with 'strict' anadeictic references. Gerner (2009, p. 73) gives examples of the use of a dedicated "familiar" (recognitional) demonstrative in Kaili Qanao, and refers to reports of exclusively recognitional demonstratives in certain Oceanic languages. Cognitively speaking, "recognitional" references via determiner that function in similar fashion to the situational reference via this form type (cf. example (1) above): in the latter type of use, the deictic expression together with its predicational context and accompanying gesture serve to construct a new discourse representation out of the representation of the utterance context which the addressee will have set up immediately prior to the indexical reference. At the same time, it effects a "figure-ground" differentiation within it, making the "figure" (the demonstratum or the intended referent itself) into a salient topic which the subsequent discourse is expected to develop. On the other hand, in the former type of reference (recognitional anadeixis), the deictic performs a similar cognitive task, but on the basis of a representation of a situation assumed to be shared by the discourse participants within their semantic or episodic memories.

\subsection{Discourse deixis}

With discourse deixis, it is the surrounding discourse just constructed which is operated upon by the addressee to appropriate the intended referent. ${ }^{11}$ This type of use of exclusively demonstrative expressions provides the basis for the existence of anaphora, according to Lyons (1977; 1979) and Bühler (1990); however, if we look ahead to Figure 2 (see the end of this section), it is evident that it is, rather, 'strict' anadeixis which would seem to have given rise to pure anaphora, judging by its adjacent position to the immediate left of the "anaphora" position on this Scale of indexical referring procedures. Contra Lakoff (1974, p. 345) as well as Piwek et al. (2008), discourse deixis is not in fact (already) anaphora, since its function is

11 See Lyons (1977), Guillot (2007), Himmelmann (1996) and Diessel (1999) on this topic. 
essentially deictic (as its name suggests). It involves an act of cognitive pointing towards the result of processing a predication (or a part of a predication) in surrounding discourse, and creating a new discourse entity out of it. In English, it may be realized by both this and that, whether as determiner or pronoun. As examples, see the use of the distal demonstrative NPs that country in (7) and that fragility in (8) below.

(7) "This is the first comprehensive study of the intonation of different languages of the world, written by a team of leading scholars in the field, most of whom are native speakers of the language in question and who live and work in that country." Book description on back cover of Hirst, D. \& Di Cristo, A. (eds.) 1998. Intonation Systems: A Survey of Twenty Languages. Cambridge University Press.

In (7), there has been no prior reference to the countries in which the languages in question are spoken by the scholars concerned, by the time the distal demonstrative NP that country occurs. The reader of this text will need to infer the referent, via the use of the deictic procedure initiated by the occurrence of the demonstrative determiner that, using the general knowledge that languages are spoken in countries by speakers who, as natives of those countries, speak the language in question as their mother tongue. The NP that country within its predicational context trades upon this item of general stereotypical knowledge (see Rubba, 1996, p. 241) in determining a set of countries for the set of world languages being referred to, and in pairing each such language with the country in which it is typically spoken. Note here the relative infelicity in this context that would be produced by substituting the definite article the for the distal demonstrative that. The infelicity created would be virtually categorical if the NP as a whole were replaced by the inanimate pronoun $i t$.

(8) “....Every day, people hide heartache and pain in public. I think audiences recognise that fragility and are drawn to it'...". (Extract from article "Pulling Power", Radio Times 1-7.08.09, p. 18).

In (8), we have a demonstrative NP also introduced by a distal demonstrative determiner, and a head noun denoting a psychological quality ('fragility') in context, which serves to re-classify (cf. Kleiber, 1984, Corblin, 1987) the other two $3^{\text {rd }}$-order referents already introduced, and to set up a general property that is reified on the basis of the more specific qualities ('heartache' and 'pain') just evoked in the previous sentence, and which it subsumes. Note that 'fragility' is not, strictly speaking, a hyperonym or superordinate of 'heartache' and 'pain' as such - rather it is a subjective characterisation on the part of the speaker. ${ }^{12}$ Like that country in (7), this is clearly a discourse-deictic occurrence. As such, the demonstrative NP that realises it within its host clause could not be replaced by a personal pronoun at all (\#...I think audiences recognise it and...): this is because an unaccented personal pronoun simply serves to carry over to its host clause domain a referent assumed to be already established as well as salient at the point of retrieval (see Figure 1). But this is not the case here: the referent needs to be constructed and installed within the current discourse model, and it is via a demonstrative-based expression (a full NP) that this is realised.

So again, discourse deixis, like its situational, 'strict' anadeictic and recognitional anadeictic counterparts, involves setting up a figure (the intended discourse referent) from within the ground in which it is embedded, and signalling that this figure is to be the subject of the subsequent discourse. The essential difference is in the nature of the 'ground' representation: unlike the situational and recognitional-anadeictic cases, this is not based on

${ }^{12}$ See Schnedecker (2006) for the various types of predicate used in demonstrative NPs in French. 
the utterance situation nor on shared representations in episodic or semantic long-term memory, but on that of the immediately prior or subsequent discourse.

How to differentiate now between the strict anadeictic and discourse-deictic functions of demonstrative-based indexicals in particular? Well, although both uses involve reference via the discourse context upstream of the occurrence of the demonstrative expression, the 'strict' anadeictic function consists in simply retrieving a referent already present within a representation of the previous discourse by 'pointing' toward it indexically (hence there is a 'deictic' aspect as well as an anaphoric component in such a use, as we have seen). But the discourse-deictic one requires the addressee or reader to operate upon a relevant contextual discourse representation in order to create a referent which was not present as such initially. Let's compare the discourse-deictic occurrences in (7) and (8) with the 'strict' anadeictic one in (9) (see also the demonstrative pronoun these in (4) above):

(9) “...'We use Viking as a shorthand term and there's the traditional raping and pillaging image of the Vikings. That was replaced in the 1970s by what I think of as the fluffy bunny school of Viking studies...".. (Extract from article by Mark Brown "'Stunning' Viking find of silver coins and jewellery bought for the nation", The Guardian 28.08.09, p. 12).

In (9), the referent of the ('strict') anadeictic demonstrative pronoun that is introduced in the initial sentence of the extract via a predicative phrase ('there's [the traditional raping and pillaging image of the Vikings]') - what's more, in focus position within an existential construction. The demonstrative could not be replaced completely felicitously via a simple pronoun (it here: ? $\underline{\text { It }}$ was replaced in the 1970s by...). This is because it is not yet installed as a topic in the reader's mental model of the discourse being constructed (the host sentence constitutes a 'thetic judgement' - see also de Mulder's 1997, p. 193 analysis of a similar French example), and needs a stronger indexical reference in order to achieve this successfully: the distal demonstrative pronoun fits the bill admirably here. Note also the distancing effect of the use of that here, in referring to the earlier image in question which has been replaced by the more recent one.

Moreover, while in (9), the demonstrative pronoun that could well be replaced by a definite NP headed by the same noun used in the antecedent-trigger expression: The image was replaced in the 1970 s by..., ${ }^{13}$ such a replacement would be either relatively or totally unacceptable in the case of (7) or (8), as we have seen: respectively, ?\#...most of whom are native speakers of the language in question and who live and work in the country and \#...I think audiences recognise the fragility and... This clearly shows that, unlike the situation in (9), the ones in (7) and (8) do not involve anaphora as such, stricto sensu. This is in direct contrast to what is claimed by Piwek et al. (2008, p. 697), namely that so-called 'discourse deixis' is in reality a form of (discourse) anaphora, simply because its interpretation 'points' backward (or forward) within the text. All this is consistent with the predictions derivable from the Scale of indexicality given in Figure 1.

Figure 2 presents the various indexical referring procedures seen so far in this article, also in the form of a Scale:

\footnotetext{
${ }^{13}$ This would be a nice illustration of the potentially anadeictic functioning that definite NPs may have in context. See also the discourse-unit initial occurrences of the definite NPs the restaurant (line 4), La Voile Rouge's owner (line 6) and the council (line 10) in text (10) below.
} 
canonical deixis $>$ discourse deixis $>$ 'recognitional' anadeixis $>$ 'strict' anadeixis $>$ canonical anaphora anadeixis

Figure 2: Scale of indexical referring procedures

The 'anadeixis' span in this Scale ranges from 'discourse deixis' to the left, to 'strict' anadeixis to the right. I have placed 'recognitional' anadeixis in between 'discourse deixis' and 'strict' anadeixis, since it is a more deictically-oriented referring procedure than the latter (the referent not being readily accessible to the addressee/reader, but needing to be retrieved from shared long-term memory). However, unlike 'discourse deixis', there does exist a referent prior to the reference effected: it is simply less immediately accessible than in the case of 'strict' anadeixis. ${ }^{14}$ This scalar conception clearly shows that with strict anadeixis, the anaphoric aspect will be dominant ('strict' anadeixis being placed on the Scale closer to the 'anaphora' pole), whereas in discourse-deixis, it is the deictic one that predominates: while with 'strict' anadeixis, the referent at issue is simply being retrieved from prior discourse, with discourse deixis, a new referent is being created and installed in the interlocutors' working memory, as it is with the use of the canonical deictic procedure.

\section{The discourse-structuring function of anadeictic indexicals}

Having established what is common to, as well as what distinguishes, deixis and anaphora and how these context-bound referring procedures operate, we come to the central part of this article: a detailed look at how they are put to use in discourse - focusing on 'strict' anadeictic and discourse-deictic occurrences, in particular. Let's look first at a fairly simple, short attested written text, a newspaper article which appeared in the British national newspaper The Guardian (3 May, 2000, p. 6). The article is reproduced in full as (10): ${ }^{15}$

\section{(10) St Tropez clean-up hits stars' hangout}

Jon Henley in Paris

i. The proprietor of La Voile Rouge beach restaurant lodged a formal appeal yesterday against the decision by St Tropez town council to shut down one of the resort's most celebrated institutions, a favourite holiday haunt of such stars as Sylvester Stallone and Mick Jagger.

ii. The restaurant, built illegally on Pampelonne beach in the heady days of 1968 and $\phi$ tolerated

5. ever since, has been caught by a council campaign to clean up St Tropez's increasingly shabby image.

iii. La Voile Rouge's owner, Paul Tomaselli, 61, said he was challenging the legitimacy of the decision. 'The committee that rules on such things was supposed to be elected by proportional representation. In fact, it was appointed by simple majority vote; that's illegal, and therefore all the committee's decisions are null and void.'

10 iv. But the council, fed up with complaints about the restaurant's loud music and the helicopters ferrying celebrities to and from a nearby helipad, is unlikely to let the matter rest.

v. 'The courts will decide $\phi$, but in theory all these beach bars and restaurants should be bulldozed,' a spokesman said. 'They are ugly, noisy, not terribly safe, and completely illegal. They have had a good run, but it is time to call it a day.'

15. vi. Mr Tomaselli's lawyer, Jean-Pierre Magnificat, said removing beach restaurants from St Tropez would be 'like banning waltzes in Vienna or beer in Munich'. (The Guardian, 3 May, 2000, p. 6: Example (2) in Cornish, 2008: 1001)

\footnotetext{
${ }^{14}$ See Kleiber (2007) on 'la deixis mémorielle' and its relationship with empathetic deixis.

15 Line numbers are given every five lines, and the paragraphs are each marked with a lower-case Roman numeral; the indexical expressions other than grammatically-determined ones (e.g. relative pronouns) used anaphorically are in italics, and those which function 'anadeictically' or purely deictically are in boldface.
} 
In terms of the text/discourse distinction which I have advocated in several recent publications (cf. Cornish, 2008, 2009b and 2010), it's clear that (textual) paragraphs particularly journalistic ones - do not always correspond to (major) discourse units (see also Hoffman, 1989, pp. 243-4): in text (10), there are 6 textual paragraphs, but arguably only 4 main discourse units: an introduction to the dispute at issue (paras i and ii), a unit presenting Mr Tomaselli's viewpoint on the dispute (para iii), a unit evoking St Tropez Town Council's position (paras iv and v), and a Coda generalising the issue (para vi). Briefly, text refers to the sequence of perceptible cues provided by the speaker (and, in the spoken, conversational mode, the addressee) on the basis of which the discourse (the provisional, situated interpretation of the ongoing sequence of utterance acts) may be co-constructed by the participants in terms both of the co-text and of a relevant, ever-evolving context.

Now, the only deictic occurrences in text (10) appear in line 1 (the primary deicticsignalling temporal expression yesterday, grounding the discourse as a whole within a particular time frame) and in the direct speech segments quoted: the distal demonstrative pronoun that in line 8 as used by the restaurant owner, Paul Tomaselli (this may be analyzed as an instance of discourse deixis), and the universally quantified proximal demonstrative NP all these beach bars and restaurants, quoted directly from the council spokesman in line $12-$ an instance of what Ehlich (1982) terms anadeixis. This anadeictic reference, designating beach bars and restaurants of the La Voile Rouge type in general, can be argued to have a macro-discourse function in that it serves precisely to extrapolate from this particular case to the more global issue of beach bars and restaurants, and in so doing to herald a shift to the Coda in paragraph vi (which evokes the issue in more general socio-cultural terms), thereby bringing the discourse to a close.

It is an anadeictic occurrence, since its reference encompasses the particular 'beach restaurant' at issue up to this point (the anaphoric dimension, then), and (via the predeterminer all and the proximal demonstrative determiner these) extends the reference to the whole class of such outlets - whence the deictic dimension. Note the plural generic reference within the Coda in line 15 to 'beach restaurants' via an indefinite bare plural NP, as well as the generically-determined agent of 'removing beach restaurants from Saint-Tropez' also expressed in lines 15-16. It is true, as Yves Bestgen (p.c.) points out, that this demonstrative occurs within a quotation, whose source is not the journalist. However, the latter has chosen to place this quotation in this strategic position, and we may assume that this was a deliberate choice on his part. News-in-brief items of this type often use direct speech quotations to reinforce earlier statements, this being the case here.

Notice that it would have been possible to use the distal demonstrative determiner those here in place of the proximal these. Indeed, there is no spatial relevance implied by such a use in this instance. In terms of the more interactive conception invoked by Laury (1997) and Östman (1995) for the equivalent Finnish expression types, and by Cheshire (1996) and Glover (2000) in the context of English conversational data, ${ }^{16}$ we might analyse this use as realising a polemical value in context, on the part of the Council spokesman: the proximal expression has the force of implying that the conception of the referent intended has not yet been 'negotiated' discursively (Glover, 2000), and so is not part of the common ground; after all, the Council's view of such bars and restaurants is thoroughly negative, and clearly the spokesman cannot expect his opponent in this dispute to share that view. The use of these here places the referent within the speaker's subjective sphere, a sphere presupposed not to be shared with his 'interlocutors'; the latter interactive value would be what the use of one of the

\footnotetext{
${ }^{16}$ See also Toupin (1998) and, for its neurolinguistic correlates, Kemmerer (1999).
} 
distal determiners that/those would have implied: see the distal demonstrative NPs in (5) and (6) above. Cf. also Fillmore (1997) in this regard.

In terms of the anaphoric or anadeictic functioning of the majority of indexical expressions in this text, it is clear that the ones most frequently used to sustain reference to the major topic entities evoked are definite full NPs and not pronouns. This is partly due to the journalistic genre of the text, which favours the use of full NPs generally, and partly to the fact that a number of these anaphoric references tend to have an important strategic, 'signposting' function within the text as a whole - cf. also Francis' (1986) notion 'anaphoric nouns' in this connection. That is, they signal the start of a new central discourse unit (or a dependent subunit) - cf. Fox (1987) in relation to repeated proper nouns in particular - and serve to 'ground' the content of that unit or subunit. So they are doing more than simply maintaining the continuity of reference which $3^{\text {rd }}$ person pronouns are specialised in realising. As such, they are in fact anadeictic rather than purely anaphoric in function, which is why I have emboldened these occurrences in the text.

See as illustration the occurrences of the definite NPs the restaurant (line 4) introducing sub-unit 1a, la Voile Rouge's owner (line 6) heading unit 2, and the council (line 10) at the head of unit 3, with the reduced, repeated proper name Mr. Tomaselli (line 15) flagging unit 4 . To show that these occurrences are not purely anaphoric, it would not be possible to replace them felicitously by $3^{\text {rd }}$ person pronouns or a possessive pronominal determiner: respectively, where the following appositional subordinate clause in the first and third of these instances is preposed to the beginning of the paragraph concerned, \#it, \#he, \#it/\#they and \#his (lawyer). This indicates that although definite NPs, like $3^{\text {rd }}$ person pronouns, may well function anaphorically, they are indexically "stronger" than the latter expression type. As such, their position to the left of $3^{\text {rd }}$ person pronouns on the Scale in Fig. 1 may be justified. See also McCarthy's (1994, p. 270) attested textual example (10), where "textual" segments (discourse units, in my terminology) are introduced mainly by definite NPs, and where $3^{\text {rd }}$ person pronouns function exclusively within these segments.

$3^{\text {rd }}$ person pronouns or zero anaphors are not intrinsically capable of fulfilling this 'announcing' or signposting function - though they may well occur initially in subunits. The tacit instruction associated with the occurrence of tokens of these expression types is to continue the psychological focus within the current textual unit. Indeed, the only overt pronouns which occur (he, it in paragraph (iii), they (twice) in paragraph (v)) refer to entities introduced within the units or subunits in which they appear. The same broad distribution pattern characterises texts (11)-(13), from a somewhat different genre, further on in the article (this section). ${ }^{17}$

Again, all these discourse-structuring, functionally-determined occurrences of tokens of the expression types concerned correspond to predictions that may be derived from the Scale of indexicality presented in Fig. 1 above.

Text (10) provided an overview of the distribution throughout a text of a variety of types of indexical expressions, each position within the text being a function of the discoursesignalling role of the types of indexical involved, and the status of the discourse unit in which they occurred. From now on, we concentrate on the specific functions in terms of discoursestructure signalling that are performed by 'strict' anadeictic and discourse-deictic occurrences.

While text (10) was a straight piece of (broadsheet) newspaper reporting, the three texts to come are all taken from the weekly radio and television magazine Radio Times. This

\footnotetext{
17 However, the occurrence of the pronoun he in line 5 of text (11) below is an exception to this pattern, since it refers across, and not within, a major discourse-unit boundary. But this anaphoric reference in its context is precisely felt to be awkward (see below for more on this issue).
} 
magazine provides a rich tapestry of data, since it contains not only radio and TV programme indications and notes, but also feature articles, interviews, advertisements, recipes and letters to the editor. Its style is characteristically relaxed and informal, often close to conversational speech. In all three examples taken from this source, there is a lot of writer-reader interaction as well as a great deal of writer involvement in the discourse (irony, tongue-in-cheek humour, wry comments and 'asides', etc.). First, then, an article presenting a dramatised TV biography:

\section{Television by Alison Graham WHAT WE'VE BEEN WATCHING Of mice and men...}

i. Breaking the Mould: the Story of Penicillin (29 July BBC4) was a delightfully old-fashioned dramatised biography of the type that wouldn't have looked out of place in the 1970s, with perhaps Robert Hardy in the lead role of Nobel Prize-winning chemist Professor Howard Florey.

5. ii. In the $\mathbf{2 0 0 9}$ version he was played by Dominic West, a hot property since The Wire, who assumed an unobtrusive Australian accent and a very unflattering parting. West also revealed a useful skill during the science bits in the lab as a man who knows how to insert mice into test tubes. He was very gentle and the stunt-mice appeared none the worse for their adventures. They probably even had a nice little cup of tea afterwards.

10. iii. If you could get past the punning title (breaking the mould/penicillin - can you see what they did there?), this was a straightforward, thoroughly workmanlike telling of a complex and not, on the face of it, eye-poppingly dramatic story. There were no car chases and no-one scaled any high buildings as Professor Florey and his team developed penicillin in huge qualities, saving countless lives. (On moral grounds, he refused to patent the process and

15. exploit it commercially).

iv. But this very earnestness was part of Breaking the Mould's retro charm. There was even a British actor (Oliver Dimsdale) with a delightful "Cherman" accent as Dr Ernst Chain, Florey's colleague. It made me go all misty-eyed for the days of Anthony Valentine as Major Mohn in Colditz. (Article in Radio Times, 8-14.08.09, p. 47)

Here, as in text $(10), 3^{\text {rd }}$ person pronouns and possessive determiners, but also reduced proper names (West, 1. 6, Florey's, 1. 18), occur almost exclusively within segments (basic discourse units, whether major or subordinate ones) and signal intra-unit continuity. As in text (10), these expression tokens are italicised. Nonetheless, there is one interesting exception to this generalisation, as was pointed out in note 16: the use of the $3^{\text {rd }}$ person singular masculine pronoun he in line 5, referring back to 'the lead role of Howard Florey', a referent introduced in the preceding paragraph (corresponding discursively to a distinct discourse unit), is awkward. The awkwardness felt by the reader here is precisely due to the conflict between the effect of referential and thematic continuity associated with the use of a $3^{\text {rd }}$ person pronoun, and the break in continuity conveyed via the start of a new textual paragraph and the occurrence at its head of a framing adverbial (the PP In the 2009 version) setting up a new discourse unit (see Charolles, 1997 on "framing adverbials": Fr. "cadratifs"). See Hofmann (1989) on the issue of $3^{\text {rd }}$ person pronouns and the infelicity associated with their referring across paragraph boundaries corresponding to major discourse units, as here.

In more macro-discourse terms, three of the four paragraphs - each one realising a discourse unit - are signalled and thus announced, first via an anadeictic definite NP (the 2009 version, a referentially non-autonomous indexical, line 5, para. ii), ${ }^{18}$ and later via demonstrative-based expressions: this in line 11 (para. iii), which has both deictic and anaphoric properties —also an 'anadeictic' occurrence, then-, and this very earnestness in line 16 (para. iv).

\footnotetext{
${ }^{18}$ See the parallel definite NPs emboldened in text (10) that announce the major discourse units of that text.
} 
Now, the latter NP is clearly a discourse-deictic occurrence, since it implicitly predicates the property of 'earnestness' of the undramatic, 'worthy' character of the action of the film highlighted in the immediately preceding paragraph, in order to make it the topic of the final, concluding paragraph (a Coda to the article as a whole). Like the anadeictic demonstrative NP all these beach bars and restaurants in text (10), this NP serves to signal a transition between major discourse units within a given text, thereby marking the concluding, 'wrapping-up' unit - though in the case of the demonstrative NP in text (10), this transition was 'heralded' rather than actually realised via the demonstrative as such.

The discourse-deictic character of the reference of this very earnestness in text (11) shows how demonstrative-based expressions occurring unit-initially in a discourse may serve to 'shift gears', discursively speaking, from a unit serving to introduce a given referent or discourse topic, to a new unit by re-classifying, encapsulating and reifying some particular aspect of what was predicated in an earlier unit in the discourse: that is, the process of interpreting such indexicals involves looking backward over the preceding discourse as well as forward to the new unit to come - this is what makes them so useful for realising this particular discourse function. Note also that, like the characterising noun fragility in that fragility in example (8), the use of the head noun earnestness in this very earnestness in (11) is a reflection of the writer's subjective evaluation of what was conveyed in unit 3 of the discourse, rather than being a lexically determined relation via some antecedent head lexeme (there isn't one here at all, in fact); the use of proximal this and not distal that in this NP is in line with this subjective element here.

Another example is from a flyer for a TV programme dealing with house-hunting:

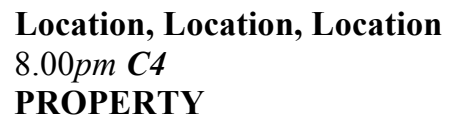

i. Phil Spencer wears an "I've seen it all now" expression when Tina, one of this week's househunters, announces that she has "dowsed"19 a map of the area in which she would like to live.

ii. Tina believes that this ancient practice, which most of us probably associate with hunting for water, will highlight both "good energy" and "bad energy" in her preferred

5 location. She's very keen and $\varnothing$ even brings in a friend to dowse a property she particularly likes. The friend finds "one energy stream". I think this is a bad thing.

iii. Tina and her husband Simon are a tricky pair. They have $£ 500,000$ to spend on a home in Kent, and $\phi$ see a succession of perfectly nice houses. But there's always a problem. One place is dismissed because Simon would have to stand for the 35-minute train journey to

10. his office in the City of London. Oh dear.

iv. Tonight's other pair of house-hunters, Charley and her husband Patrick, are more open-minded, and $\phi$ are looking for their first family home after decades of $\phi$ living in Army accommodation.

(Article by Alison Graham, Radio Times, 15-21 August 2009, p. 80)

Text (12) may be analysed in discourse terms as comprising four basic discourse units, here each corresponding to the (textual) paragraph divisions, as is also the case in text (11): an introduction to the issue of house-hunting (para i), a unit linking 'dowsing' (see note 18) and house-hunting (para ii), followed by two units each dealing with one of the two couples involved in house-hunting in the programme at issue.

Notice how it is demonstrative-based expressions (emboldened in the text) that serve to signal the topic as well as discourse status of the majority of the main units (one of this week's house-hunters (lines 1-2) for unit 1, this ancient practice (line 3 ) for unit 2, and Tonight's other pair of house-hunters (line 11) for unit 4). While the first and third of these

${ }^{19}$ To dowse: "to search for hidden water or minerals with a divining rod" (Penguin English Dictionary 1992, p. 278). 
demonstrative-based expressions realise canonical deixis, the second is arguably a discoursedeictic occurrence, predicating as it does the property of being 'an ancient practice' of the activity of 'dowsing' evoked in the first unit/paragraph: replacing the demonstrative determiner this by the definite article would not result in a totally felicitous text (?\#...the ancient practice...), ${ }^{20}$ nor (were the appositive relative clause following practice in lines 3-4 to be removed) would replacing the NP as a whole by a personal pronoun: \#Tina believes that

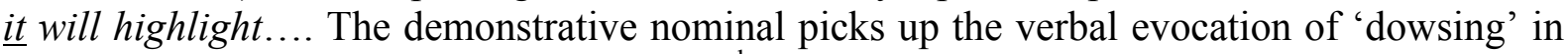
unit 1 , and creates out of it a nominal $2^{\text {nd }}$-order referent by generalising and reifying the notion, thereby acting as a marker for the second unit as a whole. As such, it functions discursively in parallel fashion to the demonstrative NP this very earnestness in text (11) though in (12), the transition is from the introductory unit to what is to be the major discourse unit in the text. In both demonstrative NPs, the properties of "being earnest" and of "being an ancient practice" are being implicitly predicated of the $2^{\text {nd }}$ order referents created via the discourse-deictic references at issue here.

Here finally is a textual example that shows the ability of demonstrative expressions to switch the focus back to the macro-frame of the text itself, which has since been overshadowed (or 'masked') by certain more recent sub-topics or units - in particular, the second (para. ii), which is background in relation to the main line of the discourse as a whole. The third unit then describes what is presented as the central scene in this episode as a whole. The text is a third short article from the magazine Radio Times:

\author{
PICK OF THE DAY \\ CSI: Miami \\ 9.00pm Five
}

i. DRAMA It must be wonderful to be Horatio Caine. He's so certain about everything. Asked by a distraught mother who's just had her baby snatched from her arms in broad daylight whether she'll ever see her child again, he confidently tells her, "You will." Yeah right, a tenmonth-old baby should be easy to find in a tiny place like Miami.

5. ii. For once, none of the whizzy CSI gadgetry helps much: a fingerprint doesn't match with any on file: DNA samples only confuse things further; and a bullet retrieved from a corpse (come on, this is CSI: Miami, at least one person has got to get shot every week) has been shattered into so many pieces it's unlikely to help with the investigation, either.

iii. But what makes this episode really worth watching is the fabulously over-the-top

10. climax in which, after a suitably dramatic car chase, Horatio emerges from the billowing smoke of a car wreck —without his trademark sunglasses. (Jane Rackham, Radio Times, 15-21 August 2009, p. 70)

\footnotetext{
${ }^{20}$ A further piece of evidence that this ancient practice is (discourse-)deictic and not merely anaphoric (or 'strict'-anadeictic) here is the fact that it occurs in a focused, foreground and not presupposed, background segment: if we apply the so-called "lie" test for focused as opposed to presupposed information (Erteschik-Shir, 2007, pp. 39,164), it is clear that it is the content of the embedded clause, not the main one, that is the point of this utterance:

(i) A: Tina believes that this ancient practice (...) will highlight both "good energy" and "bad energy" in her preferred location.

B: That's wrong! It won't.

(ii) A: (as per (i))

B: \#That's not true! She doesn't.
}

If it is felicitous to contradict a given phrase or clause within an utterance, then that phrase or clause is asserted (conveys focal information in context) and is not presupposed (this is the case in (i) above). However, if the contradiction is infelicitous, then it is claimed to correspond to backgrounded and not to asserted information (the case of the modalizing subject and matrix verb in (i) as well as (ii)). The test should be construed in relative, not absolute terms: it is the relative degree of ease with which the contradiction may be realised that is said to reflect the degree of "foregroundedness" of the information unit at issue. See the very similar test used by Boye and Harder (2009, p. 21) in terms of what the authors call "addressability", as applied to their Danish examples (16) and (17). 
The first discourse unit (para i) is an 'entrée en matière', plunging the reader in media res by evoking the triggering event for this particular episode of CSI: Miami, an event which, tongue in cheek, illustrates the main protagonist Horatio Caine's personality. The second unit (para ii), marked out via the anadeictic definite NP the whizzy CSI gadgetry, ${ }^{21}$ deals with the inability of these technologically sophisticated devices to help detect the source of the kidnapping in this instance; and the third, and arguably main discourse unit in the text (para iii), highlights the climax of the film which is claimed to be the key element in the episode as a whole. This third unit is anchored or grounded via the use of the proximal demonstrative NP this episode: this occurrence serves to switch the focus of attention back to this instalment of the series as a whole, after the concentration in units 1 and 2 on certain less essential scenes as well as details. Like the definite NP the whizzy CSI gadgetry, it is clearly anadeictic in function here. See also in this regard the use of the two tokens of the proximal demonstrative pronoun this in line 7 and in text (11) (line 11). As in the case of the transition from the penultimate unit to the final, concluding unit in text (11), the co-presence of the connective But serves to reinforce the switching of the cognitive spotlight onto the scene described in this unit.

\section{Conclusion}

Now, the discourse-deictic occurrences of demonstratives that initiate a paragraph in written texts have several of the key properties that have been assigned to framing adverbials: see Charolles (1997). An example of the latter is the PP in the 2009 version which introduces the second paragraph (as well as the second discourse unit) in text (11) (line 5). This PP signals a boundary with regard to the preceding segment (para i) which mentioned a possible earlier, 1970's version of this biography, and at the same time the start of a new unit dealing, precisely, with the 2009 version which is the topic of the article as a whole. Moreover, it provides a topic frame within which the predications falling within the second textual paragraph (and in fact the whole of the rest of this text) are to be understood and integrated.

Indeed, like framing adverbials, discourse-deictic demonstratives (as well as 'anadeictic' definite NPs) may also mark the end of a preceding discourse unit and the start of a new one (that is, they may signal boundaries between units: the textual segmentation function, claimed to be a property of the use of framing adverbials); and second, where they are full NPs, they take wide scope over the sentences as utterances that immediately follow them, in terms of their descriptive context (the integration function). ${ }^{22}$ Key examples are this very earnestness in (11) and this ancient practice in (12). Note also that, like true framing adverbials, these demonstrative expressions occur at the beginning of the discourse unit they serve to mark out. Moreover, as is generally the case with demonstrative NPs, their descriptive content is not presupposed of their referent, but serves to (re-)classify the previous discourse material the expression operates on, or it implicitly predicates some new property of it (cf. Maes and Noordman, 1995). At the same time, discourse-deictic demonstratives show properties of connectives, linking up with the previous unit. ${ }^{23}$

\footnotetext{
21 This would be an instance of 'recognitional' anadeixis, as described earlier in $\$ 3.2$ (see examples (5) and (6)). It implies an "aside" to the reader of the kind "you know the one(s) I mean!" that we saw in the case of the two examples just mentioned. Definite NPs, as is the case with the whizzy CSI gadgetry in (13), may well realise recognitional anadeixis (though not always: in (5) and (6), for example, the substitution of the for the two occurrences of that in the relevant cases would not in fact enable the NPs in question to signal recognitional anadeixis).

22 See Charolles (1997), Bestgen et al. (2009) and Charolles et al. (2009) for justification of these two functions in the case of framing adverbials.

${ }^{23}$ In fact, Diessel (1999), (2006) claims that this use actually gives rise, diachronically, to grammatical connectives.
} 
This is a reflection of their (residual) anaphoric dimension (see Figure 2). It is their essentially deictic dimension that is responsible for the forward-looking character of such references - since all uses of demonstratives (whether pure deictic or anadeictic) result in the conveying of new information in context (cf. De Mulder, 1998; Kleiber, 1984, 1994): introducing a new referent, or a new perspective on an existing referent. The user's obligatory transit, as it were, via the immediate context of utterance of the demonstrative in search of an 'index' (or demonstratum) in order to ultimately yield a referent for it, means that its use will occasion a break in the continuity of the discourse at that point. This break corresponds to the boundary demarcation which certain types of demonstrative expressions may realise, and the new information to which they give rise in context accounts for their forward-looking dimension.

All these intrinsic properties make demonstratives (and to some extent, definite NPs where used either deictically or 'anadeictically' as well) particularly effective devices for realising the specific discourse-structuring functions we have seen in this article: heralding a shift from a series of units focusing on a specific instance to a more general, subsuming cultural frame, and hence preparing the reader for a transition to a new and concluding discourse unit (all these beach bars and restaurants in text (10)); actually effecting the transition from one major discourse unit to another by encapsulating the essential discourse content of the preceding unit and making it into the topic of the following one (this very earnestness in text (11) and this ancient practice in text (12)); and finally, switching the focus of attention from units dealing with background events to the macro-frame of the discourse as a whole (this episode in text (13)).

\section{Acknowledgements}

This is a revised and expanded version of a paper initially presented at the International Symposium 'Linguistic and Psycholinguistic Approaches to Text Structuring', Ecole Normale Supérieure, 45 Rue d'Ulm, 75005 Paris, 21-23 September 2009. The title of the paper was 'Anaphoric and discoursedeictic uses of demonstratives in structuring discourse: How are they to be distinguished, and what are their discourse-structuring roles?'. A further presentation took place within the Workshop on 'Situational and Non-Situational Uses of Demonstratives' at the $43^{\text {rd }}$ meeting of the Societas Linguistica Europaea, University of Vilnius, Lithuania on $3^{\text {rd }}$ September 2010 , under the title

" "Anadeixis" and discourse deixis via demonstratives: Textual signals of discourse structure'. I am grateful to Yves Bestgen, Walter de Mulder and Alfons Maes for their comments on a revised version of this text, and to the two anonymous $L S$ referees for their detailed reading of the version submitted to the journal.

\section{References}

Bell, A. 1991. Ch. 6: Stylin' the News: Audience design. In: The Language of News Media. Blackwell, Oxford, pp. 104-125.

Bestgen, Y., Charolles, M., Piérard, S., Sarda, L. 2009. The discourse functions of sentenceinitial adverbials: studies in comprehension. Invited plenary lecture presented at the international conference Linguistic and Psycholinguistic approaches to Text Structuring, École Normale Supérieure, 45 Rue d’Ulm, Paris, 21-23 September 2009, 714.

Bosch, P., Umbach, C. 2007. Reference determination for demonstrative pronouns. ZAS Papers in Linguistics 48, 39-51.

Bosch, P., Katz, G., Umbach, C. 2007. The non-subject bias of German demonstrative pronouns. In: Schwarz-Frisel, M., Consten, M., Knees, M. (Eds.), Anaphors in Text. John Benjamins, Amsterdam/Philadelphia, pp. 145-164. 
Boye, K., Harder, P. 2009. Evidentiality: Linguistic categories and grammaticalization. Functions of Language 16(1), 9-43.

Bühler, K. 1990. Theory of Language: The representational function of language. John Benjamins, Amsterdam.

Charolles, M. 1997. L'encadrement du discours : Univers, Champs, Domaines et Espaces. Cahier de Recherche Linguistique 6. LANDISCO, URA-CNRS 1035 Université Nancy 2.

Charolles, M., Fagard, B., Sarda, L. 2009. Do framing adverbials make good connectives? Plenary talk presented at the Symposium Linguistic and Psycholinguistic approaches to Text Structuring, Ecole Normale Supérieure, 45 Rue d'Ulm, Paris, 21-23 September 2009.

Cheshire, J. 1996. That jacksprat: an interactional perspective on English that. Journal of Pragmatics 25, 369-93.

Clark, E. 1978. From gesture to word: On the natural history of deixis in language acquisition. In: Bruner, J. S., Garton, A. (Eds.), Human Growth and Development. Oxford University Press, Oxford, pp. 85-120.

Clark, H.H., Bangerter, A. 2004. Ch. 2: Changing ideas about reference. In: Noveck, I.A., Sperber, D. (Eds.), Experimental Pragmatics. Palgrave Macmillan, Basingstoke \& New York, pp. 25-49.

Consten, M. 2003. Towards a unified model of domain-bound reference. In: Lenz F. (Ed.), Deictic Conceptualisation of Space, Time and Person. John Benjamins, Amsterdam/Philadelphia, pp. 223-248.

Corblin, F. 1983a. Défini et démonstratif dans la reprise immédiate. Le Français Moderne 51(2), 118-133.

Corblin, F. 1983b. Les désignateurs dans les romans. Poétique 54, 119-211.

Corblin, F. 1987. Indéfini, défini et démonstratif. Droz, Geneva.

Corblin, F. 1995. Les formes de reprise dans le discours. Anaphores et chaînes de référence. Presses Universitaires de Rennes, Rennes.

Cornish, F. 1999. Anaphora, Discourse and Understanding. Evidence from English and French. Clarendon Press, Oxford.

Cornish, F. 2001. 'Modal' that as determiner and pronoun: the primacy of the cognitiveinteractive dimension. English Language and Linguistics 5.2, 297-315.

Cornish, F. 2007. English demonstratives: Discourse deixis and anaphora. A discoursepragmatic account. In: Nilsen, R. A., Appiah Amfo, N. A., Borthen, K. (Eds.), Interpreting Utterances: Pragmatics and its interfaces. Essays in honour of Thorstein Fretheim. Novus Press, Oslo, pp. 147-166.

Cornish, F. 2008. How indexicals function in texts: Discourse, text, and one neo-Gricean account of indexical reference. Journal of Pragmatics 40(6), 997-1018.

Cornish, F. 2009a. Indexicality by degrees: Deixis, 'anadeixis' and (discourse) anaphora. Paper presented at a Symposium (Quel sens pour la linguistique?) organized to mark the conferral of a doctorate honoris causa on Sir John Lyons, Université de ToulouseLe Mirail, 23-24 April, 2009.

Cornish, F. 2009b. Inter-sentential anaphora and coherence relations in discourse: A perfect match. Language Sciences 31(5), 572-592.

Cornish, F. 2010. Anaphora: Text-based or discourse-dependent? Functionalist vs. formalist accounts. Functions of Language 17.2, 207-240.

De Mulder, W. 1997. Les démonstratifs : des indices de changement de contexte. In: Flaux, N., Van de Velde, D., De Mulder, W. (Eds.), Entre général et particulier : les déterminants. Artois Presses Université, Arras, pp. 137-125. 
De Mulder, W. 1998. Du sens des démonstratifs à la construction d'univers. Langue Française 120, 21-32.

De Mulder, W. 2007. Demonstrative Noun Phrases, Givenness, and Relevance Theory. In: Nilsen, R. A., Appiah Amfo, N. A., Borthen, K. (Eds.), Interpreting Utterances: Pragmatics and its interfaces. Essays in honour of Thorstein Fretheim. Novus Press, Oslo, pp. 167-184.

De Mulder, W., Vetters, C. 2008. Le sens fondamental de maintenant : un token-reflexive. Cahiers Chronos 20, 15-33.

Diessel, H. 1999. Demonstratives. Form, function, and grammaticalization. John Benjamins, Amsterdam/Philadelphia.

Diessel, H. 2006. Demonstratives, joint attention, and the emergence of grammar. Cognitive Linguistics 17(4), 463-489.

Ehlich, K. 1982. Anaphora and deixis: Same, similar, or different? In: Jarvella, R. J., Klein, W. (Eds.), Speech, place and action. Studies in deixis and related topics. Wiley, Chichester, pp. 315-338.

Epstein, R. 2002. The definite article, accessibility, and the construction of discourse referents. Cognitive Linguistics 12(4), 333-378.

Erteschik-Shir, N. 2007. Information Structure. The syntax-discourse interface. Oxford University Press, Oxford.

Fillmore, C.J. 1997. Lectures on Deixis. CSLI Publications, Stanford, California.

Fox, B.A. 1987. Discourse Structure and Anaphora: Written and conversational English. Cambridge University Press, Cambridge.

Francis, G. 1986. Anaphoric Nouns. English Language Research, Birmingham.

Gary-Prieur, M-N., Noailly, M. 1996. Démonstratifs insolites. Poétique 105, 111-120.

Gerner, M. 2009. Deictic features of demonstratives: A typological survey with special reference to the Miao group. Canadian Journal of Linguistics/Revue canadienne de linguistique 54(1), 43-90.

Glover, K. 2000. Proximal and distal deixis in negotiation talk. Journal of Pragmatics 32, 915926.

Guillot, C. 2007. Entre anaphore et deixis : l'anaphore démonstrative à fonction résomptive. In: Trotter, D. (Ed.), Actes du XXIVè Congrès International de Linguistique et de Philologie Romanes, Vol. 3, Aberystwyth 2004. Tübingen, Max Niemeyer Verlag, pp. 307-315.

Hanks, W. F. 1992. The indexical ground of deictic reference. In: Duranti, A., Goodwin, C. (Eds.), Rethinking Context: Language as an interactive phenomenon. Cambridge University Press, Cambridge, pp. 43-76.

Hanks, W. F. 2009. Fieldwork on deixis. Journal of Pragmatics 41,10-24.

Hawkins, J. 1978. Definiteness and Indefiniteness. A Study in Reference and Grammaticality Prediction. Croom Helm, London.

Himmelmann, N. P. 1996. Demonstratives in narrative discourse: A taxonomy of universal uses. In: Fox, B.A. (Ed.), Studies in Anaphora. John Benjamins Amsterdam/Philadelphia, pp. 205-254.

Hofmann, T.R. 1989. Paragraphs. \& anaphora. Journal of Pragmatics 13, 239-250.

Jones, P. 1995. Philosophical and theoretical issues in the study of deixis: A critique of the standard account. In Green, K. (Ed.), New Essays in Deixis. Discourse, Narrative, Literature. Rodopi, Amsterdam/Atlanta, pp. 27-48.

Karmiloff-Smith, A. 1980. Psychological processes underlying pronominalization and nonpronominalization in children's connected discourse. In: Kreiman, J., Ojeda, A. (Eds.), Papers from the Parasession on Pronouns and Anaphora. Chicago Linguistic Society, Chicago, 231-249. 
Kemmerer, D. 1999. 'Near' and 'far' in language and perception. Cognition 73, 35-63.

Kleiber, G. 1983. A propos de l'analyse adjectif démonstratif = article défini + élément déictique ou: Sur l'irréductibilité des symboles indexicaux. In: Actes du VIIe congrès international de linguistique et de philologie romanes, Aix-en-Provence, 29 August-3 September 1983, Vol A, pp. 195-212.

Kleiber, G. 1984. Sur la sémantique des descriptions démonstratives. Linguisticae Investigationes VIII/1, 63-85.

Kleiber, G. 1986a. Adjectif démonstratif et article défini en anaphore fidèle. In: David, J., Kleiber, G. (Eds.), Déterminants: syntaxe et sémantique. Klincksieck, Paris, pp. 169185.

Kleiber, G. 1986b. Pour une explication du paradoxe de la reprise immédiate. Langue Française 72, 54-79.

Kleiber, G. 1990. Sur l'anaphore démonstrative. In : Charolles, M., Fisher, S., Jayez, J. (Eds.), Le discours. Représentations et interprétations. Presses Universitaires de Nancy, Nancy, pp. 243-263.

Kleiber, G. 1994. Anaphores et pronoms. Duculot, Louvain-la-Neuve.

Kleiber, G. 1998. Les démonstratifs à l'épreuve du texte ou sur cette côte de la baie d'Arguenon. Langue Française 120, 77-94.

Kleiber, G. 2006. Démonstratifs : emplois à la mode et mode(s) d'emploi. Langue Française $152,9-23$.

Kleiber, G. 2007. Des démonstratifs mémoriels aux démonstratifs de point de vue. In: Begioni, L., Muller, C. (Eds), Problèmes de sémantique et de syntaxe. Hommage à André Rousseau. Editions du Conseil Scientifique de l'Université Charles de GaulleLille 3, Villeneuve d'Ascq, pp. 373-392.

Kleiber, G. 2008. Comment fonctionne ICI? Cahiers Chronos 20, 113-145.

Lakoff, R. 1974. Remarks on this and that. In: Proceedings of the Tenth Regional Meeting of the Chicago Linguistic Society. Chicago Linguistic Society, 345-356.

Lapaire, J-R., Rotgé, W. 1992. Linguistique et grammaire de l'anglais. Presse Universitaires du Mirail, Toulouse.

Laury, R. 1997. Demonstratives in Interaction. The emergence of a definite article in Finnish. John Benjamins, Amsterdam/Philadelphia.

Levinson, S. C. 2004. Deixis. In: Horn, L.R., Ward, G. (Eds.), The Handbook of Pragmatics. Blackwell Publishing, Malden, MA, USA/Oxford, UK/Carlton, Australia, pp. 97-121.

Lyons, C. 1999. Definiteness. Cambridge University Press, Chicago.

Lyons, J. 1975. Deixis as the source of reference. In: Keenan, E. L. (Ed.), Formal Semantics of Natural Language. Cambridge University Press, Cambridge, 61- 83. Reprinted as Ch. 8 in Lyons, J. 1991, Natural Language and Universal Grammar. Cambridge University Press, Cambridge, pp. 146-165.

Lyons, J. 1977. Ch. 15: Deixis, space and time. In: Semantics, Vol 2. Cambridge University Press, Cambridge, pp. 636-724.

Lyons, J. 1979. Deixis and anaphora. In: Myers, T. (Ed.), The Development of Conversation and Discourse. Edinburgh University Press, Edinburgh, pp. 88-103. Reprinted as Ch. 9 in Lyons, J. 1991, Natural Language and Universal Grammar. Cambridge University Press, Cambridge, pp. 166-178.

Lyons, J. 1982. Deixis and subjectivity: Loquor, ergo sum? In: Jarvella, R. J., Klein, W. (Eds.), Speech, place and action. Studies in deixis and related topics. Wiley, Chichester, pp. 101-124.

Maes, A. 1996. Nominal anaphors, markedness, and the coherence of discourse. Peeters, Leuven. 
Maes, A., Noordman, L. 1995. Demonstrative nominal anaphors: a case of nonidentificational markedness. Linguistics 33, 255-282.

Martin, J.R. 1992. Ch. 3: Identification. Reference as semantic choice. In: English Text: System and structure. John Benjamins, Amsterdam/Philadelphia, pp. 93-157.

McCarthy, M. 1994. It, this and that. In: Coulthard, M. (Ed.), Advances in Written Text Analysis. Routledge, London and New York, pp. 266-275.

Nunberg, G. 1993. Indexicality and deixis. Linguistics and Philosophy 16, 1-43.

Oakley, T. 2009. Mental spaces. In: Brisard, F., Östman, J-O., Verschueren, J. (Eds.), Grammar, Meaning and Pragmatics. John Benjamins, Amsterdam/Philadelphia, pp. 161178.

Östman, J-O. 1995. Recasting the deictic foundation, using Physics and Finnish. In: Shibatani, M, Thompson, S.A. (Eds.), Essays in Semantics and Pragmatics in honor of Charles J. Fillmore. John Benjamins, Amsterdam/Philadelphia, pp. 247-278.

Piwek, P., Beun, R-J., Cremers, A. 2008. 'Proximal' and 'distal' in language and cognition: Evidence from deictic demonstratives in Dutch. Journal of Pragmatics 40, 694-718.

Recanati, F. 2005. Ch. 6: Deixis and anaphora. In: Gendler Szabó, Z. (Ed.), Semantics versus Pragmatics. Clarendon Press, Oxford, pp. 286-316.

Rubba, J. 1996. Alternate grounds in the interpretation of deictic expressions. In: Fauconnier, G., Sweetser, E. (Eds.), Spaces, Worlds, and Grammar. University of Chicago Press, Chicago, pp. 227-261.

Schnedecker, C. 2006. Les démonstratifs "prédicatifs »: qu'est-ce qui limite leur apport informatif? Langue Française 152, 39-55.

Tanz, C. 1980. Studies in the Acquisition of Deictic Terms. Cambridge University Press, Cambridge.

Toupin, F. 1998. Référence et deixis : le cas de this et that adverbes. In: Le Querler, N., Gilbert, E. (Eds.), La Référence - 1 - Statut et processus. Presses Universitaires de Rennes, Rennes, pp. 65-84. 